\title{
Direction of outward FDI of EMNEs: Evidence from the Indian pharmaceutical sector
}

\author{
Sumon Kumar Bhaumik \\ Aston Business School, Aston University, UK; \\ IZA - Institute for the Study of Labour, Bonn; and \\ William Davidson Institute, Ann Arbor \\ s.bhaumik@aston.ac.uk
}

Nigel Driffield

Economics and Strategy Group, Aston Business School, Aston University n.l.driffield@aston.ac.uk

\begin{abstract}
This paper seeks to add to the small but growing literature of emerging market MNEs. Using a two linked large firm level data bases, it seeks to explore the determinants of the direction of outward investment of Indian pharmaceutical companies, i.e., developed vs. developing country destinations. It specifically examines the impact of two firm-level characteristics that embody "non-OLI" firm-specific capabilities of EMNEs. The finding of this study is that family firms (and business group affiliations) that were optimal responses to institutional and market failures, and hence are ubiquitous in emerging markets, are keen on investing in other developing countries but much less so in developed countries. However, international linkages not only facilitate overseas investment of EMNEs in general, they also help (partly) offset the disinclination of family firms to invest in the latter countries.
\end{abstract}




\section{Introduction}

Outward FDI from emerging markets is one of the most prominent phenomena in the current round of globalisation. In 2005, outward FDI from the developing countries was $\$ 117$ billion or $15 \%$ of the worldwide flow of FDI (UNCTAD, 2006). Correspondingly, the stock of outward FDI by emerging market multinational enterprises (EMNEs) rose from $\$ 72$ billion in 1980 (and \$149 billion in 1990) to over \$1 trillion at the end of 2005. Indian EMNEs have participated in this process of global expansion to a significant extent (Narula \& Dunning, 2000). According to UNCTAD, outward FDI flow from India has grown from an average of $\$ 121$ million per year during the $1990-2000$ period to $\$ 9.67$ billion in 2006 , registering a much faster pace of growth than outward FDI from China.

India's pharmaceutical industry has played a leading role in this internationalization process. Data on 306 cross-border acquisitions by Indian firms during the 2000-06 period indicates that pharmaceutical sector firms were involved in $20 \%$ of the acquisitions, second only to their software sector counterparts (Nayyar, 2008). These figures are consistent with the growth of the sector since the initiation of liberalisation in 1991. Even though the turnover of the industry, estimated at $\$ 6$ billion, is small relative to the $\$ 550$ billion worldwide turnover, it has a growth rate of about $10 \%$, compared with the $7 \%$ compounded annual growth rate of the global turnover. India's leading drug manufacturers like Ranbaxy, Dr. Reddy's and Cipla are emerging as world players, utilizing organic growth and improved organizational capabilities within a highly competitive domestic market. In 2005, Indian companies accounted for $75 \%$ of the domestic market (compared to only $20 \%$ in 1970) and nine out of top 10 companies where domestically owned (compared with just 4 as late as 1994). Further, they are globally integrated, with exports to over 65 countries accounting for about $\$ 3.7$ billion (i.e., $62 \%$ ) of the turnover (KPMG, 2006).

In this paper, we use firm-level data from the Indian pharmaceutical industry to address the question as to what determines the direction of outward FDI of EMNEs, towards developed and developing countries. The literature has empirically examined the drivers of outward FDI of EMNEs itself (see Bhaumik, Driffield \& Pal, 2010, and relevant references 
therein), organisational changes associated with the internationalisation process (Chittoor, Sarkar, Ray \& Aulakh, 2009), and post-FDI issues such as the impact of internationalization on EMNE performance (Kumar \& Singh, 2008). There is also a discussion in the literature about the internationalisation strategies of EMNEs (Ramamurti, 2009).Finally, there are descriptive analyses of the geographical direction of outward FDI of emerging markets such as China (Morck, Yeung \& Zhao, 2008; Ramamurti \& Singh, 2009). But none have attempted to explicitly examine the impact of firm-specific capabilities of EMNEs, which are generally different from the innate capabilities that are discussed in the OLI literature, on the direction of outward FDI. Yet, an understanding of the determinants of the direction FDI of these EMNEs have significant implications for discussions about issues such as south-south economic cooperation and the extent to which, in the post-financial crisis era, the highly indebted developed countries can expect to attract investment from the cash rich emerging markets, and therein lies the main contribution of our paper.

We focus on firm-specific characteristics of emerging market companies that can potentially provide a competitive edge in overseas markets in the same way that ownership of technologies, patents and brand identities provide a competitive edge to developed country MNEs. In particular, we focus on family ownership of firms, and equity stake by foreign investors in these companies. It is stylised in the literature that family ownership of firms is an optimal outcome of institutional environments in emerging economies, and it can potentially offer certain advantages, for example, by reducing agency costs within firms and thereby reducing the within-firm transactions costs for decision-making and contract enforcement (Goffee \& Scasse, 1985; Daily \& Dollinger, 1992; Poza, Alfred \& Maheshwari, 1997). Similarly, the literature also documents the advantages of equity stake by foreign investors in emerging market firms. Among other things, these foreign investors provide linkages to overseas markets that facilitate learning about business environments in these markets (Mathews, 2006; Elango \& Patnaik, 2007). In our analysis, therefore, we bring together the stylised OLI view of capability, the institutional view that emphasises non-traditional 
ownership advantages, the management-agency theory literature, and alternative IB views about outward FDI of EMNEs like the LLL paradigm of Mathews (2006).

Our analysis has implications for broad issues such as south-south economic cooperation and the extent to which, in the post-financial crisis era, the highly indebted developed countries can attract investment from cash rich emerging markets. It also has implications for management strategy of emerging market firms that aim to invest in developed country markets with which they might not be familiar.

The rest of the paper is structured as follows: In Section 2, we review the (largely empirical) literature on outward FDI by EMNEs, and use this literature to formulate our hypotheses. In Section 3, we briefly review the trends in the pharmaceutical sector in India, and discuss the data used for the analysis. In Section 4, we introduce the regression model, report the regression estimates, and discuss their implications for the hypotheses developed earlier in the paper. Finally, in Section 5, we discuss the implications of the results for the wider literature on EMNEs and the limitations of our study, and suggest ways in which our analysis can be extended.

\section{Hypotheses}

The stylised OLI paradigm suggests that MNEs have innate capabilities that they leverage to offset disadvantages associated with factors such as distance and cultural difference when they operate in other countries. In the traditional IB literature, which focuses on MNEs from developed countries, such capabilities include proprietary technology, brand recognition, and highly evolved production and management processes. By contrast, EMNEs typically do not have such firm-specific advantages, at least during the early stages of internationalisation. Indeed, it has been argued that EMNEs internationalise to acquire such firm-specific advantages (Mathews, 2002; Luo \& Tung, 2007). Rugman (2008) has argued that EMNEs might, therefore, be more reliant on country-specific advantages during their initial forays into the outside world. Examples of country-specific advantages include scale and scope efficiencies associated with large domestic markets (e.g., China and India), access to key 
natural resources like petroleum (e.g., Russia), or support from the state and its apparatus (Buckley et al., 2007, 2008; Fleury \& Fleury, 2008). It is evident that while some of these country-specific advantages are innate (e.g., resource abundance or market size), others are outcomes of policies adopted by the home-country governments of EMNEs.

Support for the view that early internationalisation of EMNEs is more likely to be facilitated by country-specific advantages than by OLI type innate advantages can be found in an earlier study of Lecraw (1993), who demonstrated that prior to undertaking outward investment, Indonesian MNEs were scale, cost and technology inefficient, even though their performance compared favourably with fellow Indonesian companies. Subsequent to undertaking overseas investment, they became export-intensive and low cost producers of high quality goods. It is evident from the discussion in the previous section that acquisition of technology is likely to be a key consideration influencing outward FDI of Indian pharmaceutical companies as they work towards overcoming technological barriers created by decades of low levels of R\&D.

However, the advantage of emerging market firms is not limited to country-specific ones such as scale efficiencies, abundant natural resources, or subsidised credit. They also have firm-specific advantages that can aid them in the internationalisation process. For example, early studies found that emerging market firms have expertise in products that are better suited for developing country customers (Lecraw, 1973; Wells, 1983). Specifically, their products are usually less sophisticated but more rugged, to suit developing country conditions, and less expensive to purchase and maintain than the products of their developed country competitors. They were able to develop these products in the era of import substitution, when they were protected from competition from overseas rivals by tariff and non-tariff barriers. Perennial shortage of key inputs like capital and skilled labour, institutional failure and insufficient public goods such as infrastructure also forces emerging market firms to be innovative and be efficient (Khanna \& Palepu, 2006). In the aftermath of liberalisation of emerging market economies, which eases access to state-of-the-art technology, they are also able to leapfrog the entrenched older technologies of their 
developed country counterparts (Williamson \& Zheng, 2008; Ramamurti, 2009). Not surprisingly, over the past two decades, emerging market companies like Embraer and Tata Steel have emerged as efficient innovators in a wide range of industries.

We seek to extend this argument, by examining the impact of two non-traditional firm-specific advantages of EMNEs on the direction of their outward FDI. The first of these is family ownership which, in emerging market contexts, also overlaps significantly with business group affiliations (Ghemawat \& Khanna, 1998; Peng \& Delios, 2006). As we have already noted, emerging market firms often have characteristics that endow them with the capability to mitigate market and institutional failures in their domestic countries, and family ownership of firms is one such characteristic. Management scholars have long viewed family ownership as the optimal response in contexts where the cost of enforcement of formal contracts is high, and hence where trust and norms are used as mechanisms to facilitate interaction among economic agents (Peng \& Heath, 1996; Yeung, 2006). Economists, in turn, argue that existence of family firms is a consequence of imperfections in the market for managerial talent or a market for corporate control (Burkart, Panunzi \& Shleifer, 2003).

Family ownership (or control) of firms can give rise to Type II or principal-principal agency problems (Young et al., 2008). However, it can also generate significant benefits for a firm. Reciprocal altruism among family members could reduce their reservation price for key resources, thereby allowing them to outbid (or undercut) non-family firms in the product market (Eaton, Yuan \& Wu, 2002). This cost advantage can be reinforced by their lower cost of enforcing within-organisation contracts that makes the decision-making process flexible (Goffee \& Scasse, 1985; Daily \& Dollinger, 1992).

Group membership too comes with several advantages. Most importantly, business groups usually have internal capital markets that enable individual member firms to mitigate the problems associated with imperfect credit and capital markets (Riyanto \& Toolsema, 2008). It has been demonstrated that membership of business groups might also act as a signal that makes it easier to access external funds (Ghatak \& Kali, 2001; Lesnik, van der Molen \& Gangopadhyay, 2003), especially if there is a credible commitment on the part of business 
groups to bail out weak member firms in the event of adverse shocks (Friedman, Johnson \& Mitton, 2003). Further, in contexts where family businesses are the optimal organisational form, given factor market imperfections and costs of contract enforcement, among other things, the existence of family-affiliated business groups can perhaps also be explained by the economies of scope associated with intangible and tangible resources such as knowledge of the business environment and distribution channels that are disproportionately concentrated in existing firms (Guillen, 2000).

In both developed and developing country (overseas) markets, these aspects of family ownership can endow emerging market firms with certain advantages like relatively low cost of capital and insulation from outcomes like liquidation in the event of adverse shocks. However, there are two important distinctions between developed and developing country markets that should also influence the outcome with respect to outward FDI. First, developing countries are often characterised by opaque legal systems and absence of rule of law such that personal relationships and informal mechanisms, as opposed to transparent contracts, are used to conduct business. Emerging market firms, which typically experience similar legal environments (more generally, institutional failure) in their home countries, are adept at operating in these environments (Khanna \& Palepu, 2006), and hence institutional weakness of developing countries per se should not act as a deterrent for them. By contrast, they may be more reluctant to subject themselves to financial and other scrutiny in developed economies, especially if the aforementioned Type II agency problems in these firms result in corporate governance problems such as expropriation of minority shareholders (Bertrand, Mehta \& Mullainathan, 2002; Baek, Kang \& Lee, 2006).

Second, while institutional similarity between home countries of emerging market firms and other developing countries could enable these firms to transfer their business models to the latter contexts, without sacrificing significant decision-making powers to local managers, changes in business models and devolution of powers to local managers might be inevitable in the event of investment in developed countries where the institutional and, more generally, the business environments are significantly different. This is likely to pose a much 
greater challenge for family (or business group affiliated) firms that, in emerging market contexts, were an optimal response to institutional weaknesses, and hence are embedded in the institutional frameworks and local cultures of these countries (Gallo \& Sveen, 1991; Chittoor et al., 2009). The problem is compounded by the reliance of these firms to depend on family ties for choice of managers, rejecting meritocracy, and thereby entering a state of "strategic simplicity", whereby they follow the same set of strategies over and over again (Zahra, 2003). Reluctance to adopt new business models and devolution of decision-making powers to local managers might make emerging market family firms more reluctant to invest in developed countries than in developing countries (Johanson \& Vahlne, 1977; Gallo \& Sveen, 1991; Tsang, 2001; Zhang \& Ma, 2008).

In other words, family-owned emerging market firms have important advantages with respect to overseas investment in both developing and developed countries. However, these advantages are offset by other factors when the context of such investment is developed countries. In the light of the existing literature (Bhaumik, Driffield \& Pal, 2010), it is reasonable to argue that the advantages would indeed be more than offset in such contexts. On the other hand, these advantages may be strengthened (or at least not be fully offset) if the context of the investment is developing countries. We, therefore, hypothesise the following:

Hypothesis 1: Family owned firms are more likely to invest a greater share of their assets in developing countries than their non-family owned counterparts. However, they are likely to invest a smaller share of their assets in developed countries than the non-familyowned firms.

Next, we examine the impact of another firm-specific advantage of emerging market firms, namely, foreign ownership of their equity. There is a large IB literature about jointventure (JV) partnerships among developed country firms and local firms in emerging markets (see Meyer, Estrin, Bhaumik \& Peng, 2009, and the references therein). However, more recently, developed country investors have often opted for the equity investment route 
to engaging with emerging market firms. For example, between 2000-01 and 2007-08, the net FDI flow to India was USD 80,216 million, while the net flow of portfolio investment, most of which is in equity, was USD 72,319 million.

Firms with foreign shareholders are not only more competitive than their local counterparts that do not attract foreign investment in their equity (Douma, George \& Kabir, 2006), they are also more informed about the institutional and business environments in the overseas markets as linkages with overseas investors facilitate learning about those markets (Mathews, 2006). Arguably, the competitive edge of emerging market firms with foreign shareholding would matter more in the context of outward FDI to developing countries where they are likely to behave like traditional MNEs aiming to capture markets or leverage local resources to improve global capabilities. Knowledge about overseas markets, on the other hand, is more likely to matter in the context of outward FDI to developed countries or institutional environments, with which these firms are less familiar. Indeed, Dunning's (1986) investment cycle theory suggests that outward FDI may be facilitated by access to knowledge and expertise embedded in investors with international experience. Firms that have attracted foreign shareholders are more likely to be aware of investment opportunities abroad, either directly through inter-firm linkages or indirectly through managerial input from the foreign investors. Further, emerging market firms in which MNEs and other foreign investors have equity stake generally have better corporate governance quality, and hence are less likely to view engaging in FDI to developed countries (with the attendant scrutiny) as an unreasonably risky strategy. Finally, the foreign investors might help ease financing constraints by facilitating loan syndication etc in the global capital market.

It is evident, therefore, that the linkages with foreign investors are likely to facilitate overseas FDI by emerging market firms to both developing and developed countries. Indeed, if such linkages significantly improve the corporate governance quality of these firms (Ramaswamy, Li \& Veliyath, 2002) and also significantly increase the knowledge of these firms about overseas markets, they might offset the reluctance of family-owned firms to invest in developed countries. We, therefore, hypothesise the following: 
Hypothesis 2: Foreign ownership of equity would facilitate outward FDI by emerging market firms to both developed and developing countries.

Hypothesis 2a: Foreign ownership of equity would at least partially offset the reluctance of family-owned emerging market firms to invest in developed countries.

\section{Research setting}

\subsection{The Indian Pharmaceutical Industry}

As mentioned earlier, the Indian pharmaceutical industry has a turnover of $\$ 6$ billion, making it the fourth largest pharmaceutical market in the world in terms of volume (KPMG, 2006). While this is a small fraction of the $\$ 500$ billion global market, the compounded annual growth rate of the Indian industry since the early 1990s (10\%), is significantly higher than the corresponding growth rate of the global industry $(7 \%)$. The growth rate of exports of the Indian industry is 30\%. Between 1996 and 2005, the export intensity of an average organised sector pharmaceutical firm rose from $15 \%$ to over $24 \%$ (Chittoor \& Ray, 2007).

The industry is characterised by over 20,000 firms, of which only $250-300$ are in the formal sector. These formal sector firms account for $70 \%$ of the industry's turnover, with the ten largest firms accounting for $30 \%$. The Indian firms account for $75 \%$ of the domestic sales, an increase of more than $200 \%$ since the early 1970 s when they accounted for $20 \%$ of the sales. In keeping with this, the number of Indian firms in the top ten in the industry rose from four in (as late as) 1994 to nine in 2005. As we have noted earlier in this paper, the ownership of the organised sector pharmaceutical companies in India is heavily concentrated, usually in the hands of families and business groups.

Finally, it should be noted that the size and growth of the Indian pharmaceutical industry does not accurately reflect its innovation capabilities. The mainstay of the Indian industry is the generics sector; Indian companies account for $22 \%$ of the global generics market. In the foreseeable future, there are opportunities to sustain the industry's growth by leveraging its competitive advantage in generics production, on account of drugs with nearly 
$\$ 65$ billion in turnover losing patent protection. However, significant threats exist in the form of real decreases in prices of generics drugs in the lucrative US market, and in the form of low cost and fully integrated generics competitors from China and Eastern Europe (KPMG, 2006).

At the same time, however, the Patent Act which came into force in January 2005 provides Indian pharmaceutical companies the incentive to enhance their capabilities to move up the value chain and launch patented products. This incentive to launch patented products is further supported by the low cost of clinical trials in India, estimated to be a tenth of the corresponding cost in the US. Indeed, perhaps in anticipation of patent protection, there was an increase in patent applications from 295 in 2001 to 784 in 2004 . However, with the average ratio of $R \& D$ expenses to sales at a low $2 \%$ for the industry and less than $5 \%$ for even the leading companies (against a global average of 10-20\%), ${ }^{1}$ and given the long time lag between investment in R\&D and marketable products, the ambitious and fast growing Indian companies have an incentive to leap forward technologically by acquiring foreign companies with complementary technology and long product pipe lines. This, in large part, explains why three quarters of the outward FDI from India has been to the US and Europe.

\subsection{Variables and specification}

Table 1 describes the variables. Our measure of the dependent variable is as follows:

Dependent variable: Our dependent variable of interest is the proportion of a firm's productive assets held overseas. However, as evident from our hypotheses, we extend this baseline analysis, by distinguishing between locations of FDI to developed and developing world. In the pharmaceuticals sector, the majority of Indian outward FDI (just over two thirds) is located in the developed world (largely the EU and North America), with the largest single location being the UK (19\% of the total), followed by the US (17\%). Of the FDI located in the developing world, over $90 \%$ of it is in East Asia, evenly divided between China

\footnotetext{
${ }^{1}$ The R\&D expenditure of the larger companies have increased significantly since the turn of the century. But even now they are miniscule relative to those of the global MNEs. For example, the combined $R \& D$ expenditure of Nicholas Piramal and Cipla, two of the ten largest pharmaceutical companies in India, accounts for less than 3\% of the R\&D expenditure of Pfizer.
} 
and South East Asia. There is a very small percentage (2\%) to other parts of to the world such as Africa and the Caribbean.

Our measures of the explanatory variables are as follows:

Family ownership (H1): We employ two alternative measures of family control. The direct measure is taken from Prowess which allows us to identify whether a family is the single largest owner of shares a firm. Following Claessens et al. (2002), we construct a binary variable $F A M$ that takes the value unity if indeed a family is the single largest shareholder in a firm. However, it is likely that this measure will understate the influence that a family or closed network of owners would have on the firm's strategic decisions. It is now stylized that ownership structures involving crossholding, control pyramids etc result in larger degree of control and cash flow rights for the family than that reflected merely by their direct ownership of shares. We therefore employ the Capital Line data, which unambiguously identifies business group affiliations, usually a correlate of family control, and we construct second binary variable $(B G R)$ that takes the value unity when a firm is affiliated to a business group. According to our data, the first measure suggests that only $15 \%$ of the firms in our sample are family-owned, an underestimate by most accounts, while the second measure gives us a more plausible figure of $23 \%$. We use these two indicators of family ownership separately in our regression models. The robustness of the estimates (qualitatively) should give us confidence about the ability of these binary indicators to capture the impact of family ownership on overseas investment.

Foreign investment $(\mathrm{H} 2 \& \mathrm{H} 2 a)$ : We capture foreign investment in the firms with F10 and F25, each a binary variable. These capture $10 \%$ and $25 \%$ ownership of shares by foreign investors, respectively. The former effectively distinguishes between portfolio investments which in these data are under $10 \%$. The latter signals a level of equity ownership at which foreign investors become more involved in the functioning of the firms. ${ }^{2}$ Since, foreign investors could influence the overseas investment decisions of family-controlled firms

2 Sarkar and Sarkar (2000) demonstrated that foreign investors have an impact on performance of domestic India firms after they reach the threshold of about $25 \%$ equity ownership. 
as well, we also include two interaction terms, namely, $I_{l}$ and $I_{2}$, between foreign ownership $(F 10, F 25)$ and family ownership (FAM or BGR).

Control variables: To begin with, we control for the embedded knowledge of the company, our measure for which is the ratio of intangible assets to total assets of a firm (INTAN). This measure is that typically employed with firm level financial data; see for example Braunerhjelm (1996). Next, we control for the size of the company, with sales (SALES) as the proxy for size. We also control for the financial ability of the company to undertake outward FDI, in the manner suggested by Baker, Foley and Wurgler (2004). Since overseas FDI is typically funded through internal funds or debt, we control for the profitability of the company (PROFIT) as well as the size of its internal accruals (CASH). Our measure of a company's debt is its debt-to-equity ratio (TDTA). The popular wisdom is that a large debt-to-equity ratio would deter a company from making further investments. If, however, the absolute level of debt-to-equity ratio is low across firms, a relatively high ratio may indicate either a greater risk appetite or greater ability to borrow by way of better relationships with the lenders. Finally, we control for a company's ability to manage overseas expansion by taking into account the number of its Indian subsidiaries (INDSUB); the more the number of subsidiaries, the greater the learning required to manage further expansion.

\subsection{Methodology}

Since the distribution of the dependent variable is left-censored at zero, the now stylized panel Tobit model is employed (Banga, 2007; Bhaumik, Driffield \& Pal, 2010). The advantages of the panel nature of the data are twofold. First, it controls for firm-specific and time invariant unobserved factors that might influence the decision to invest overseas using firm-specific fixed effects. Second, in order to mitigate endogeneity problems of the explanatory variables, we lag them by one time period such that, for example, the sales in period $t-1$ affect the extent of overseas investment in period $t$.

We also take into account the possibility that that firms that have greater global visibility are more likely to attract investment from abroad. If so, the foreign holdings 
variables may be endogenous in the outward FDI decision. To ensure that lagging the explanatory variables addresses this potential endogeneity problem, we also test for endogeneity of the two indicators foreign ownership (F10 and F25) using the Tobit-specific methodology developed by Smith and Blundell (1986). For each of these variables, the value of the test statistic, which follows a $t$ distribution, is less than one, and it is therefore appropriate to treat these variables as exogenous.

Our regression specification, therefore, is given by the following:

$$
\begin{aligned}
\mathrm{FDI}_{\mathrm{it}}= & \beta_{0}+\beta_{1} \mathrm{OWN}_{\mathrm{i}, \mathrm{t}-1}+\beta_{2} \mathrm{~F}_{2} 5_{\mathrm{i}, \mathrm{t}-1}+\beta_{3} \mathrm{~F}_{10} \mathrm{i}_{\mathrm{i}, \mathrm{-}-1}+\beta_{4} \mathrm{I}_{1}+\beta_{5} \mathrm{I}_{2} \beta_{6} \mathrm{INTAN}_{\mathrm{i}, \mathrm{t}-1}+ \\
& +\beta_{7} \text { SALES }_{\mathrm{i}, \mathrm{t}-1}+\beta_{8} \mathrm{CASH}_{\mathrm{i}, \mathrm{t}-1}+\beta_{9} \mathrm{INDSUB}_{\mathrm{i}, \mathrm{t}-1}+\beta_{10} \text { PROFIT }_{\mathrm{i}, \mathrm{t}-1} \\
& +\beta_{11} \text { TDTA }_{\mathrm{i}, \mathrm{t}-1}+\mathrm{u}_{\mathrm{i}}+\varepsilon_{\mathrm{it}}
\end{aligned}
$$

when $i$ refers to the $i^{\text {th }}$ firms, $t$ and $t-1$ refer to time periods, $O W N$ is the indicator of family ownership which could be either $F A M$ or $B G R, I_{l}$ is the interaction between $O W N$ and $F 10, I_{2}$ is the interaction between $O W N$ and $F 25, u_{i}$ is the firm-specific fixed effect and $\varepsilon_{i}$ is the iid error term. We estimate this regression model separately for outward FDI to developed and developing countries.

Our hypotheses have the following implications for the coefficient estimates:

\section{Developed Developing}

$\begin{array}{llll}\text { Hypothesis } 1 & \text { implies } & \beta_{2}<0 & \beta_{2}>0 \\ \text { Hypothesis } 2 & \text { implies } & \beta_{3}, \beta_{4}>0 & \beta_{3}, \beta_{4}>0 \\ \text { Hypothesis } 2 a & \text { implies } & \beta_{5}, \beta_{6}>0 & \beta_{5}, \beta_{6}>0\end{array}$

\subsection{Data and summary statistics}

Our data is taken from Orbis, a rich firm level dataset, which is provided by Bureau van Dijk electronic publishing (BvD). The dataset used in this paper is the mid-version of Orbis that includes detailed financial company accounts (balance sheets and Profit and Loss accounts) for Indian companies. The selection criteria for inclusion of firms is based on satisfying at least one of the following conditions: number of employees equal to at least 20 , total 
operating revenues of at least $\$ 1.5$ million, and total assets equalling at least $\$ 3$ million. The dataset also provides information on overseas productive assets of the companies, thereby providing us with our measure for outward FDI. After accounting for missing data, we have information on 581 pharmaceutical sector firms, of which 44 firms $(7.5 \%)$ report outward FDI.

We supplement the Orbis data with additional ownership information obtained from the Prowess data base that includes information on share-ownership of various categories of institutional and non-institutional owners, both domestic and foreign. Ownership data included in Prowess has been widely used in the relevant literature on Indian companies (e.g., Bertrand et al., 2002). We also have obtained information on the firm's affiliation to business groups, from the Capital Line data archive.

Table 2 presents summary statistics and the correlations between these variables. The descriptive statistics suggest that the Indian firms that invest overseas are larger, with average sales of INR 223,296 as opposed to INR 195,249 for all firms. The former also manage more Indian subsidiaries (10.16) than the latter (1.95). In so far as the variables of interest are concerned, the proportion of intangible assets as a proportion of total assets is similar for the (Indian) MNEs (0.73) and for the overall sample of firms (0.79). However, there is as a proportion, five times as many firms in the overall sample are family controlled (15\%) as in the sample of MNEs (3\%). Finally, global MNEs have significantly larger minority equity stakes in the Indian firms that invest overseas $(F 10=22 \%$ and $F 25=18 \%)$ than in the overall sample $(F 10=11.3 \%$ and $F 25=4.2 \%)$.

The correlation matrix is not suggestive of any significant multicollinearity, with the understandable exception for the correlation between profitability (PROFIT) and internal accruals (CASH). However, standard VIF tests confirm that the multicollinearity is not a problem; the value of the test statistic is 3.4 , well under the normal threshold of 5 .

\section{Results}


The estimated coefficients of the Tobit model are reported in Table 3. In columns (1a) and (2a), we report the regression estimates for outward FDI to developed countries, while in columns (1b) and (2b) we report the regression estimates for developing countries. Note also that columns (1a) and (1b) report the estimates of the model that uses FAM as the measure of family ownership, while columns (2a) and (2b) report the estimates of the model that uses $B G R$ as the measure of family ownership. The pseudo R-square values, which suggest that our specification marginally better explains inter-firm variation in outward FDI to developing countries, are comparable to those in research on emerging markets (e.g., Bhaumik, Driffield \& Pal, 2010).

The results have the following implications for our hypotheses:

Hypothesis 1: The regression coefficients indicate that, in keeping with Hypothesis 1, family owned Indian firms are less likely to invest in developed markets than their non-family owned counterparts, but more likely than the latter to invest in developing countries. The result is robust to our proxy for family ownership - FAM or $B G R$ - but stronger when FAM is the proxy for family ownership. The general conclusion that we can perhaps draw from this is that, despite the allure of large markets and access to cutting edge technology, investment in developed countries may not be the preferred option for a large proportion of emerging market firms whose corporate landscape is often dominated by family owned companies. In part, this highlights the comparative advantage of emerging market family owned companies in developing country business environments. It part, it also echoes the findings of Bhaumik et al. (2010) that corporate governance structures significantly influences outward FDI decisions of emerging market firms. It is also consistent with the observation that while EMNE investment in developed countries is generally associated with family owned firms, closer scrutiny shows that it is not a widespread phenomenon, the same firms/business groups are involved in multiple incidents of outward FDI (e.g., the Tata Group, the Aditya Birla Group, Vedanta Industries, Mahindra and Mahindra, and Ranbaxy from India). This has significant implication for the quantum of investment that cash strapped developed countries 
in Europe and North America can expect from the cash rich developing country companies in the foreseeable future.

Hypotheses 2 and $2 a$ : Our regression estimates suggest that minority yet significant shareholding by foreign investors in the Indian companies facilitate FDI to all destinations; F10 and F25 have positive and significant coefficients for the regression models for both developed and developing countries. This is consistent with Hypothesis 2. As mentioned earlier, this is also consistent with the view that presence of foreign shareholders provides a linkage with the overseas markets and thereby mitigates informational problems, thereby facilitating overseas investment (Dunning, 1986; Mathews, 2006). The interesting implication of this result is the interdependence between the developed countries and emerging markets; while emerging market firms require the knowledge of and disciplining by foreign investors (usually from developed countries) to facilitate their overseas investment, developed countries themselves need to build relationships with emerging market firms to entice investment from these cash rich firms.

The interaction terms demonstrate that even for family-controlled firms, foreign investment reduces the risk associated with FDI. This is consistent with Hypothesis 2a. As argued earlier in the paper, presence of foreign shareholders can potentially help in three ways, namely, information about overseas markets and their business environment, better corporate governance, and easing financial constraints. However, foreign shareholding in these firms has to be large enough to have a significant offsetting effect. For example, for developed countries, while $B G R$ has a coefficient of -0.14 , the interaction between this proxy for family ownership and $F 25$ and $F 10$ are 0.09 and 0.01 , respectively. Hence, the net effect for family owned firms with $10-25 \%$ foreign shareholding is -0.13 , while the net effect for firms with at least $25 \%$ minority foreign shareholding is only -0.05 .

Other variables: It can be seen that the extent of overseas FDI increases substantially with an increase in the embedded knowledge of the company, as measured by the value of its intangible assets (INTAN). Larger firms are less likely to invest in developing countries, though size has no impact on the decision to invest in OECD countries. One possible 
interpretation of this result is that Indian pharmaceutical MNEs are market seeking, and hence, other things being given, are not attracted to developing countries that have relatively small markets. An alternative explanation, however, is that larger firms are better prepared to move up the value chain, and hence shun markets in which investment is unlikely to give them access to technology and patents. A similar asymmetry can be observed in the impact of PROFIT on investment in developed and developing countries. Profitable companies are less likely to invest in developing countries, even though profitability does not have any impact on investment in developed countries. Since cash flow (CASH) significantly impacts outward FDI to both developing and developed countries, and given that access to the credit market (as reflected by the debt to equity ratio: TDTA) do not affect outward FDI to either developed or developing countries it is difficult to rule out the importance of internal accruals in facilitating cross-border investment. The asymmetric result with respect to profitability might therefore reflect both the strategic ambition of profitable firms to expand market for their products and acquire capabilities, both of which would be limited in a developing country context. Finally, prior experience in managing subsidiaries, as captured by the number of Indian subsidiaries of the companies (INDSUB) facilitates outward FDI to both developed and developing countries.

In sum, the regression results are consistent with both our hypotheses and with the wider literature on the behaviour of MNEs. The regression models are also sensible, with significant explanatory power, as reflected in the (pseudo) R-square values of $0.29-0.34$ that are fairly large for a cross section sample of 541 companies. This is also verified by the high correlation of $0.50-0.68$ between the actual and predicted values of the dependent variable. It is interesting that in general the model works better for the developing countries data. As with most empirical models of FDI, ours was developed from the conceptual framework of that emphasises the ability of MNEs.to use their capabilities for a competitive edge in overseas markets. Our goodness-of-fit measures suggest, quite reasonably, that EMNEs are much more likely to have such an edge in other developing country markets than in developed countries. 
Indeed, it is a vote of confidence for our decision to widen the scope of capabilities to include emerging market specific measures such as ownership structure.

\section{Discussion}

Recent years have witnessed rise of EMNEs as major players in the global market. FDI from countries such as India is on the increase, both to Europe and North America, as well as to countries where the relevant sectors are less developed than India. In this context, the present paper examines the choice of direction of outward FDI of MNEs in the Indian pharmaceutical sector which has emerged as a global player but has received much less attention in the academic research relative to the dramatic growth of Indian software in the 1990s. Overall, the results presented here suggests that, in keeping with the rapidly growing literature on EMNEs (Mathews, 2006; Rugman, 2008; Ramamurti, 2009), firm characteristics that reflect firm-specific capabilities of emerging market firms explain well outward FDI from India.

Perhaps the most significant result reported in this paper is that family firms in emerging markets like India are likely to invest more in other developing countries and, correspondingly, less is developed countries. While this result is not completely surprising, given competitive advantage of emerging market firms in other developing countries and, perhaps even more importantly, the similarity of institutional quality across developing countries (and the difference in this quality between developed and developing countries), this is the first rigorous evidence to support this hypothesis. Given that a significant proportion of the large and cash rich firms in emerging markets are family owned, there are two important implications of this observation. First, private sector driven FDI is likely to emerge as an important component of increasing south-south cooperation that is currently driven by trade and government investment. Second, if the developed world wants to attract larger investments from the cash rich firms in the emerging markets, they would have to engage with these firms to a significant extent, whether though equity ownership or in any other way. However, as there is institutional convergence between the developed world and at least the fast growing emerging markets, EMNE investment in the developed countries is likely to 
increase. While some of this convergence can be negotiated - e.g., accounting laws and corporate governance structures - others aspects of such convergence can only take place in the long run.

The analysis has important implications for emerging market firms as well, those that want to invest in developed countries. It suggests that strategies that were optimal for the preliberalisation period of emerging market economies may prove to be a deterrent for strategic expansion in the post-liberalisation era, as explicit institutions such as enforceable contract law reduce or eliminate the need for implicit contracts and norms that were best suited for the pre-liberalisation era. Owners (or majority shareholders) of these firms should be more open to dilution of control, with ownership spread among a wider range of stakeholders who can add to the firm's portfolio of knowledge about markets, products and operational best practices. In particular, management of such companies should adopt strategies and corporate governance practices that make their shares attractive to developed country investors. They would also have to be prepared for greater devolution of decision making process to local managers in host countries and, in general, be more receptive to ideas from outside close networks of friends and family.

This line of research can (and should) be extended in several ways. To begin with, it would be important to ascertain whether there is a hierarchy in FDI flows from emerging economies, is it that the "best" firms seek to invest in richer countries, while investing in developing countries is seen as a cheaper form of internationalisation? If this indeed is the case, there are adverse implications for the FDI related spillovers for the recipient developing countries. Further, whether the returns generated from EMNEs' investment in developing and developed countries are comparable, i.e., whether the developing country bias of family firms in emerging markets has significant implications for their profitability, warrants further examination. This might require linking the literature on EMNEs to the more general international finance literature based on Doukas and Lang (2003). Further, in view of the debate about outsourcing, and the inconclusive findings about its impact on the productivity of developed country firms, it would be interesting to examine whether developed country 
industries that forge links with emerging markets by way of outsourcing are also more likely to attract EMNE investment. Finally, attempts should be made to address the question as to whether there should be greater focus on achieving convergence between the accounting standards, corporate governance standards, contract law and other relevant aspects of the institutional environment in developed countries and emerging markets, thereby eliminating an important part of the rationale for the developing country bias of family owned EMNEs. 


\section{References}

Baek, J-S., Kang, J.K., \& Lee, I. 2006. Business groups and tunnelling: Evidence from private securities offerings by Korean chaebols. Journal of Finance, 61: 2415-2449.

Baker, M., Foley, C.F. \& Wurgler, J. 2004. The stock market and investment: evidence from FDI flows. Working paper no. 10559, National Bureau of Economic Research, Cambridge, Massachusetts.

Banga, R. 2007. The export-diversifying impact of Japanese and US foreign direct investments in the Indian manufacturing sector. Journal of International Business Studies, 37: 558-568.

Bertrand, M., Mehta, P., \& Mullainathan, S. 2002. Ferreting out tunnelling: An application to Indian business groups. Quarterly Journal of Economics, 117: 121-148.

Bhaumik, S., Driffield, N. and Pal, S. 2010. Does ownership concentration affect MNE operations? The case of Indian automobiles and pharmaceuticals. Journal of International Business Studies, 41: 437-450.

Braunerhjelm, P. 1996. The relation between firm-specific intangibles and exports. Economic Letters, 53: 213-219.

Buckley, P.J., Clegg, L.J., Cross A.R., Liu, X., Voss, H. \& Zheng, P. 2007. The determinants of Chinese outward foreign direct investment. Journal of International Business Studies, 38(4): 499-518.

Buckley, P.J., Clegg, L.J., Cross A.R., Voss, H., Rhodes, M., \& Zheng, 2008. Explaining China's outward FDI: An institutional perspective. In Sauvant, K.P., Mendoza, K. \& I. Ince (Eds), The rise of transnational corporations from emerging markets: Threat or opportunity?: 104-157. Cheltenham: Edward Elgar Publishers.

Burkart, M., Panunzi, F. \& Shleifer, A. 2003. Family firms. Journal of Finance, 58: 21672202.

Chittoor, R. \& Ray, S. 2007. Internationalization paths of Indian pharmaceutical firms: A strategic group analysis. Journal of International Management, 13: 338-355.

Chittoor, R., Sarkar, M.B., Ray, S. and Aulakh, P.S. 2009. Third-world copycats to emerging multinationals: Institutional changes and organizational transformation in the Indian pharmaceutical industry. Organization Science, 20: 187-205.

Claessens, S, Djankov, S., Fan, J.P.H., \& Lang, L.H.P. 2002. Disentangling the incentive and entrenchment effects of large shareholdings. Journal of Finance, 57: 2741-2471.

Cummings, J.L. \& Teng, B-S. 2003. Transferring R\&D knowledge: The key factors affecting knowledge transfer success. Journal of Engineering and Technology Management, 12: 39-68.

Daily, C.M. \& Dollinger, M.J. 1992. An empirical examination of ownership structure in family and professionally managed firms. Family Business Review, 5(2): 117-136.

Doukas, J.A. and Lang, L.H.P. (2003) 'Foreign Direct Investment, Diversification and Firm Performance', Journal of International Business Studies, 34(2): 153-172.

Douma, S., George, R., \& Kabir, R. 2006. Foreign and domestic ownership, business groups, and firm performance: Evidence from a large emerging market. Strategic Management Journal, 27: 637-657.

Dunning, J. H. (1979). 'Explaining Changing Patterns of International Production: In Defence of the eclectic theory'. Oxford Bulletin of Economics and Statistics, 41 (4): 269-95.

Dunning, J.H. 1986. The investment cycle revisited. Weltwirtschaftliches Archiv, 122: 667677.

Eaton, C., Yuan, L., \& Wu, Z. 2002. Reciprocal altruism and the theory of the family firm. Paper presented at the Second Annual Conference on Theories of the Family Enterprise: Search for a Paradigm. Philadelphia, PA.

Elango, B. \& Pattnaik, P. 2007. Building capabilities for international operations through networks: A study of Indian firms. Journal of International Business Studies, 38: 541-555. 
Fleury, A. \& Fleury, M.T.L. 2008. Brazilian multinationals: Surfing the waves of internationalization. In Ramamurti, R. \& Singh, J.V. (eds.) Emerging Multinationals from Emerging Markets: 200-243. Cambridge, UK: Cambridge University Press.

Friedman, E., Johnson, S. \& Mitton, T. 2003. Propping and tunnelling. Journal of Comparative Economics, 31: 732-750.

Gallo, M.A., \& Sveen, J. 1991. Internationalizing the family business: Facilitating and restraining factors. Family Business Review, 4: 181-190.

Ghatak, M. \& Kali, R. 2001. Financially interlined business groups. Journal of Economics and Management Strategy, 10: 591-619.

Ghemawat, P. \& Khanna, T. 1998. The nature of diversified business groups: a research design and two case studies. Journal of Industrial Economics, 46: 35-61.

Goffee, R. \& Scasse, R. 1985. Proprietorial control in family firms: Some functions of 'quasiorganic' management systems. Journal of Management Studies, 22(1): 53-68.

Guillen, M.F. 2000. Business groups in emerging economies: A resource-based view. Academy of Management Journal, 43: 362-380.

Johanson, J. \& Vahlne, J.E. 1977. The internationalisation process of the firm: A model of knowledge development and increasing foreign market commitments, Journal of International Business Studies, 8(1): 23-32.

Khanna, T. \& Palepu, K. 2006. Emerging giants: Building world-class companies in developing countries. Harvard Business Review, October.

KPMG 2006. The Indian Pharmaceutical Industry: Collaboration for Growth, KPMG London.

Kumar, V. \& Singh, N. 2008. Internationalisation and performance of Indian pharmaceutical firms. Thunderbird International Business Review, 50(5): 321-330.

Lecraw, D.J. 1993. Outward direct investment by Indonesian firms: Motivation and effects/ Journal of International Business Studies, 24: 589-600.

Lesnik, R., van der Molen, R. \& Gangopadhyay, S. 2003. Business groups, financing constraints and investment: The case of India. Journal of Development Studies, 40: 93-119.

Luo, Y. \& Tung, R.L. 2007. International expansion of emerging market enterprises: A springboard perspective. Journal of International Business Studies, 38: 481-496.

Mathews, J.A. 2002. Dragon multinationals: A new model for global growth. Oxford, UK: Oxford University Press.

Mathews, J.A. 2006. Dragon multinationals: New players in $21^{\text {st }}$ century globalisation. Asia Pacific Journal of Management, 23(1): 5-27.

Meyer, K.M., Estrin, S., Bhaumik, S.K., \& Peng, M. 2009. Institutions, resources, and entry strategies in emerging economies. Strategic Management Journal, 30(1): 61-80.

Morck, R., Yeung, B. \& Zhao, M. 2008. Perspectives on China's outward foreign direct investment. Journal of International Business Studies, 39: 337-350.

Narula, R. \& Dunning, J.H. 2000. Industrial development, globalisation and multinational enterprises: New realities for developing countries. Oxford Development Studies 28(2): 141-167.

Nayyar, D. 2008. The internationalization of firms from India: Investment, mergers and acquisitions. Oxford Development Studies, 36(1): 111-131.

Peng, M.W. \& Delios, A. 2006. What determines the scope of the firm over time and around the world? An Asia Pacific perspective. Asia Pacific Journal of Management, 23: 385-406.

Peng, M.W. \& Heath, P.S. 1996. The growth of the firm in planned economies in transition: Institutions, organisations, and strategic choice. Academy of Management Journal, 21(2): 492-528.

Poza, E.J., Alfred, T. \& Maheshwari, A. 1997. Stakeholder perceptions of culture and management practices in family and family firms: A preliminary report. Family Business Review, 10(2): 135-155. 
Ramamurti, R. 2009. What have we learned about EMNEs? In R. Ramamurti \& J. V. Singh (Eds), Emerging multinationals from emerging markets. Cambridge: Cambridge University Press.

Ramamurti, R. \& Singh, J.V. 2009. Indian multinationals: Generic internationalization strategies. In R. Ramamurti \& J.V. Singh (Eds), Emerging multinationals from emerging markets. Cambridge: Cambridge University Press.

Ramaswamy, K., Li, M., \& Veliyath, R. 2002. Variations in ownership behaviour and propensity to diversify: A study of the Indian corporate context. Strategic Management Journal, 23: 345-358.

Riyanto, Y.E. \& Toolsema, L.A. 2008. Tunnelling and propping: A justification for pyramidal ownership. Journal of Banking and Finance (forthcoming).

Rugman, A. 2008. Theoretical aspects of MNEs from emerging markets. In Ramamurti, R. \& Singh, J.V. (eds.) Emerging Multinationals from Emerging Markets: 42-63, Cambridge, UK: Cambridge University Press.

Sarkar, J., \& Sarkar, S. 2000. Large shareholder activism in corporate governance in developing countries: Evidence from India. International Review of Finance, 1(3): 161-194.

Smith, R.J., \& Blundell, R.W. 1986. An exogeneity test for a simultaneous equation Tobit model with an application to labor supply. Econometrica, 54: 679-685.

Szulanski, G. 1996. Exploring internal stickiness: Impediments of transferring the best practice within the firm, Strategic Management Journal, 17, 27-43.

Tsang, E.W.K. 2001. Internationalizing the family firm: A case study of a Chinese family business. Journal of Small Business Management, 39: 88-94.

UNCTAD 2006. World Investment Report, United Nations Conference on Trade and Development, Geneva.

Yeung, H. 2006. Change and continuity in Southeast Asian Chinese business. Asia Pacific Journal of Management, 23: 229-54.

Young, M.N., Peng, M.W., Ahlstrom, D., Brutton, G.D. \& Jiang, Y. 2008. Corporate governance in emerging economies: A review of the principal-principal perspective. Journal of Management Studies, 45(1): 196-220. 
Table 1: Variable definitions

\begin{tabular}{|c|c|}
\hline \multicolumn{2}{|c|}{ Dependent variable } \\
\hline FDI & $\begin{array}{l}\text { The proportion of a firm's assets held overseas, in developed or } \\
\text { developing countries }\end{array}$ \\
\hline \multicolumn{2}{|c|}{ Variables of interest } \\
\hline FAM & $\begin{array}{l}\text { Dummy }=1 \text { if a family is the largest shareholder in the a firm, one } \\
\text { proxy for family ownership (Hypothesis } 1 \text { ) }\end{array}$ \\
\hline BGR & $\begin{array}{l}\text { Dummy=1 if firm is part of a wider business group, another proxy for } \\
\text { family ownership (Hypothesis 1) }\end{array}$ \\
\hline F25 & $\begin{array}{l}\text { Dummy }=1 \text { if a firm has minority foreign holding of at least } 25 \% \\
\text { (Hypothesis 2) }\end{array}$ \\
\hline F10 & $\begin{array}{l}\text { Dummy }=1 \text { if a firm has minority foreign holding of between } 10 \% \text { and } \\
25 \% \text { (Hypothesis 2) }\end{array}$ \\
\hline $\mathrm{FAM} \times \mathrm{F} 25$ & Interaction between FAM and F25 (Hypothesis $2 a$ ) \\
\hline $\mathrm{FAM} \times \mathrm{F} 10$ & Interaction between FAM and F10 (Hypothesis $2 a$ ) \\
\hline \multicolumn{2}{|c|}{ Control variables } \\
\hline INTAN & Intangible assets as a proportion of total assets (Hypothesis 1) \\
\hline SALES & Sales \\
\hline $\mathrm{CASH}$ & Cash flow \\
\hline INDSUB & The number of Indian subsidiaries of the firm \\
\hline PROFIT & Profitability $=$ EBIT $/$ total assets \\
\hline TDTA & Leverage $=$ total debt $/$ total assets \\
\hline
\end{tabular}


Table 2: Summary statistics and correlation matrix

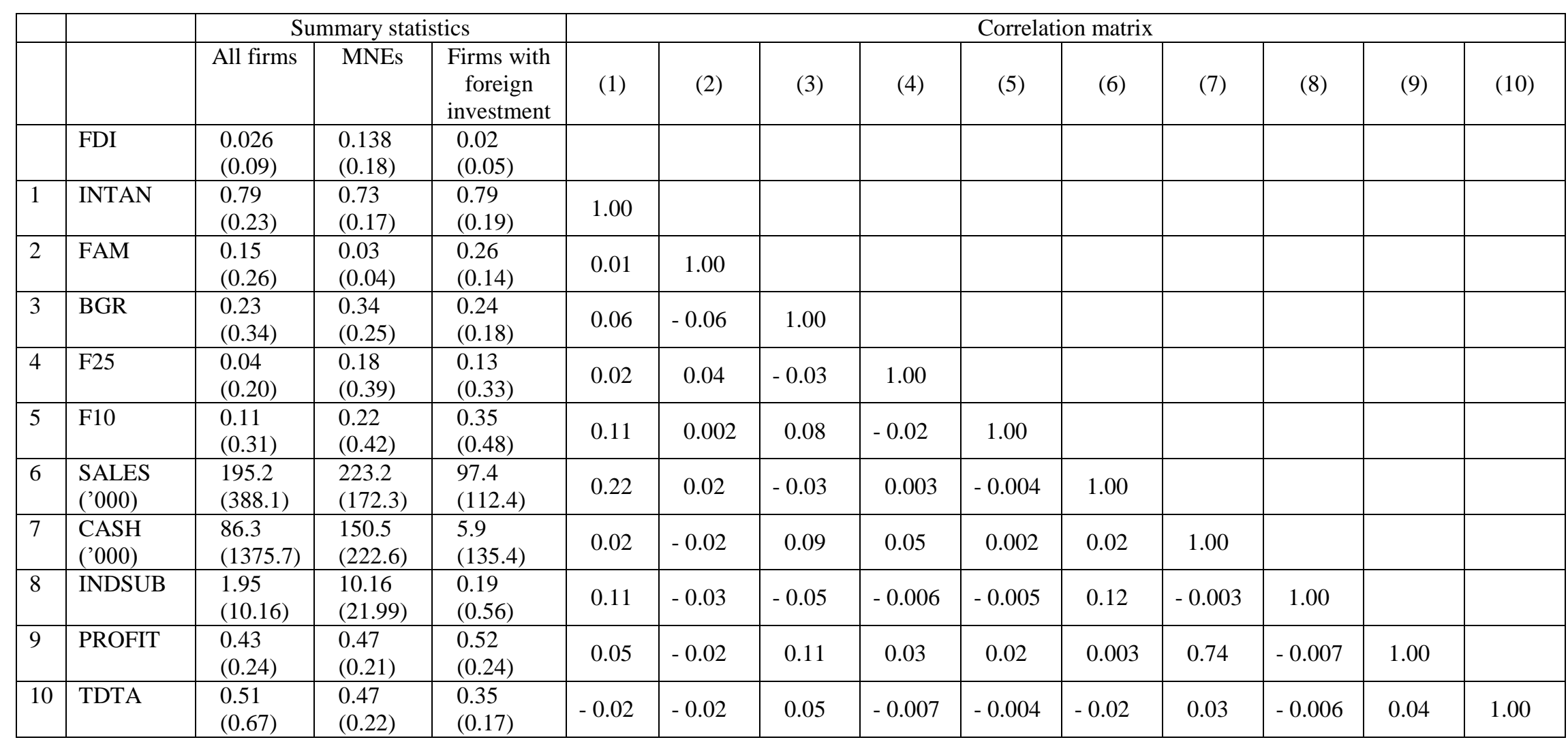

Notes: (i) The summary statistics are averages for the 1996-2005 period. (ii) The values within parentheses are standard deviations. 
Table 3: Regression results

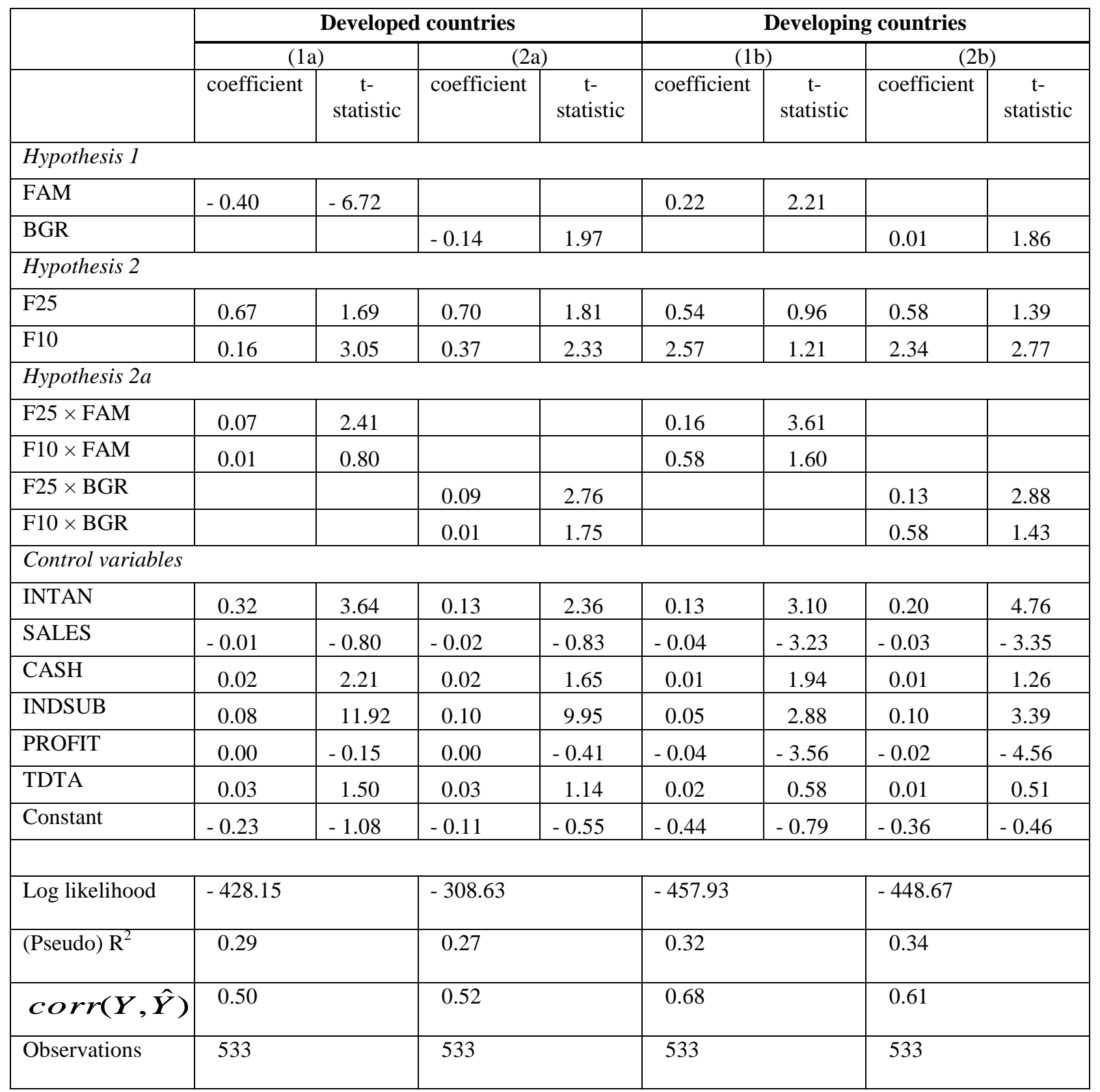

